\title{
Faktor Genetik Sebagai Risiko Kejang Demam Berulang
}

\author{
Tjipta Bahtera, Susilo Wibowo, AG Soemantri Hardjojuwono \\ Bagian Ilmu Kesehatan Anak FK Universitas Diponegoro/RS. Dr. Kariadi Semarang
}

\begin{abstract}
Latar belakang. Sepertiga pasien kejang demam pertama mengalami bangkitan ulang kejang demam. Riwayat keluarga adalah pernah kejang demam dan mutasi gen merupakan faktor risiko bangkitan kejang demam berulang.

Tujuan. Membuktikan faktor genetik sebagai risiko terjadi kejang demam berulang.

Metode. Rancangan penelitian kohort prospektif. Subjek pasien kejang demam pertama, selama 18 bulan diamati terjadi bangkitan ulang kejang demam. Amplifikasi DNA dengan teknik PCR dan sequencing untuk melihat mutasi gen pada kanal ion Natrium. Pengujian hipotesis memakai regresi logistik, dan uji korelasi memakai Rank Sperman corelation.

Hasil. Sepertiga pasien kejang demam pertama mengalami kejang demam berulang. Mutasi gen kanal ion $\mathrm{Na}^{+}$SCNIA 19(61,3\%) pasien, terdapat pergantian Argenin (R) oleh asam glutamat (Glu) (Arg1627Glu) (mutasi missense) dan kodon stop (TGA).(mutasi nonsense), sedangkan pada SCNIB 12(38,7\%) pasien, terdapat mutasi heterozigot, yaitu kodon 130:GAA /AAA, kodon 96:CGG/TGG, kodon 138:GTC/ATC, kodon 95:AGC /ATT dan kodon:154 GCT/AAT. Ada hubungan mutasi gen dengan umur, suhu dan riwayat keluarga pernah kejang demam, saat kejang pertama. (koefisien korelasi berturut-turut -0,359; -0,339; 0,278). Riwayat keluarga pernah kejang demam dan mutasi gen berisiko 2-3 kali terjadi kejang demam berulang (RR 2.9, $p<0,05$ dan RR $3.556 p>0,05$ )

Kesimpulan. Sepertiga pasien kejang demam pertama mengalami kejang demam berulang. Riwayat keluarga pernah kejang demam dan mutasi gen merupakan faktor risiko kejang demam berulang. Terdapat hubungan mutasi gen dengan umur, suhu dan riwayat keluarga pernah kejang demam, saat kejang pertama. (Sari

Pediatri 2009;10(6):378-84).
\end{abstract}

Kata kunci: kejang demam, mutasi gen kanal Natrium

\section{Alamat Korespondensi:}

Tjipta Bahtera, dr., Sp.A (K). Bagian IKA FK UNDIP/RS.Dr. Kariadi Semarang. Jl Dr. Soetomo No.16-18 Semarang, Jawa Tengah 50231.

Telp. 024. 8311471 . Fax. 024. 8414296

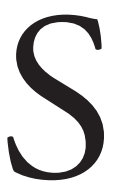

ekitar 25\%-50\% pasien kejang demam pertama akan mengalami bangkitan ulang kejang demam. ${ }^{1-5}$ Terdapat hubungan antara faktor genetik dengan bangkitan ulang kejang demam. ${ }^{6}$ Faktor genetik adalah riwayat keluarga pernah menderita kejang demam dan mutasi gen. Pasien 
kejang demam pertama dengan riwayat keluarga (first degree relative) pernah menderita kejang demam mempunyi risiko 50\%-100\% terjadi bangkitan ulang kejang demam., ${ }^{2,7}$

Tujuan penelitian untuk mengetahui hubungan faktor genetik terhadap bangkitan kejang demam berulang.

\section{Metode}

Penelitian dilakukan terhadap pasien kejang demam pertama di RS Roemani dan RS Pantiwilasa I. Sampel diambil secara consecutive sampling. Subyek untuk pemeriksaan DNA diambil dengan nested case control. Pemeriksaan mutasi gen pintu voltase kanal ion $\mathrm{Na}^{+}$ subunit $\alpha$ (SCN IA) diperiksa di kromosom 2 q24 exon 26 dan subunit $\beta$ (SCN IB) di kromosom 19q13 exon 3, dikerjakan di Biotek ITB Dilakukan amplifikasi $D N A$ dengan tehnik PCR dan sequencing untuk melihat adanya mutasi gen pintu kanal voltase ion $\mathrm{Na}^{+}$. Primer yang dipakai adalah, untuk SCN IA Dan IB.

Primer untuk SCN IA adalah Forward ( SCN IA 26-1Fb ): $5^{\prime}$ gtt tct tgc cga gct gat agg 3' (dirancang oleh Biotek ITB) dan Reverse ( SCN IA 26-1R ): 5' gcg tag atg aac atg act agg 3' (sesuai referensi). Untuk Primer untuk (SCN IB) adalah Forward (SCN IB 3 F): $5^{\prime}$ cct tcc cct ccc tgg cta 3' (sesuai referensi) dan Reverse (SCN IB 3R): 5' ggc agg cag cac ccg act cac 3' (sesuai referensi).

Berdasarkan perhitungan besar sampel ditetapkan 47 pasien. Pengelolahan data dan analisis memakai program computer SPSS 11.5. Hubungan antara faktor genetik dengan bangkitan kejang demam berulang memakai analisis ganda logistitik dan diskriminan Hubungan antara channelopathy dengan umur, suhu tubuh, periode waktu antara mulai demam sampai bangkitan kejang, jenis kejang dan riwayat keluarga pernah kejang demam saat kejang pertama memakai analisis korelasi rank Spearman correlation.

\section{Hasil}

Subjek penelitian 148 pasien, umur rata-rata $(16,6$ $\pm 9,8)$ bulan terdiri dari laki-laki $94(63,4 \%)$ dan perempuan 54 (36,5\%). Lima puluh enam $(37,84 \%)$ anak mengalami bangkitan kejang demam berulang. Bangkitan ulang kejang demam pertama terjadi kurang dari 12 bulan terjadi pada $87,5 \%$ dan kurang dari 24 bulan $94,7 \%$ kasus. Periode waktu antara mualai demam dan kejang $(23,9 \pm 26,9)$ jam, periode waktu antara kejang pertama dan berulang $(8,4 \pm 7,5)$ bulan, dan frekuensi bangkitan kejang demam berulang selama pengamatan $(2,7 \pm 0,76)$ kali (Tabel 1$)$.

Sepertiga pasien kejang demam mempunyai keluarga (first degree relative) dengan riwayat pernah menderita kejang demam, yaitu ibu, ayah atau saudara kandung berturut-turut 24 (16,2\%), 17 (11,5\%), dan $10(6,8 \%)$ (Tabel 2).

Tiga puluh enam pasien diperiksa mutasi gen, didapatkan $31(86,1 \%)$ mutasi. Mutasi gen pintu

Tabel 2. Riwayat keluarga pernah menderita kejang demam

\begin{tabular}{lc}
\hline \multicolumn{1}{c}{ Hubungan keluarga } & $\begin{array}{c}\text { Riwayat pernah kejang demam } \\
(\mathrm{n}, \%)\end{array}$ \\
\hline Ayah & $17(11,5)$ \\
Ibu & $24(16,2)$ \\
Saudara kandung & $10(6,8)$ \\
First degree relative & $45(30,4)$ \\
\hline
\end{tabular}

Tabel 1. Karakteristik subjek

\begin{tabular}{|c|c|c|c|c|}
\hline Variabel & Minimum & Maksimum & Median & Rerata $\pm S B$ \\
\hline Umur (bulan) & 2 & 58 & 14 & $16,6 \pm 9,8$ \\
\hline Suhu tubuh (Celcius) & 37,5 & 42 & 39 & $39,1 \pm 0,82$ \\
\hline $\begin{array}{l}\text { Periode waktu antara mulai demam } \\
\text { dengan kejang (jam) }\end{array}$ & 0,3 & 120 & 12 & $23,9 \pm 26,9$ \\
\hline $\begin{array}{l}\text { Periode waktu di antara kejang pertama } \\
\text { dan kejang demam berulang (bulan) }\end{array}$ & 0,5 & 42 & 6 & $8,4 \pm 7,5$ \\
\hline $\begin{array}{l}\text { Frekuensi bangkitan kejang demam } \\
\text { berulang selama pengamatan (kali)* }\end{array}$ & 2 & 4 & 3 & $2,7 \pm 0,76$ \\
\hline
\end{tabular}

* Pengamatan selama 18 bulan 
Tjipta Bahtera dkk: Faktor Genetik Sebagai Risiko Kejang Demam Berulang

Tabel 3. Mutasi gen pada pintu voltase kanal ion $\mathrm{Na}^{+}$subunit SCNIA dan SCNIB*

\begin{tabular}{lcc}
\hline \multirow{2}{*}{ Pemeriksaan DNA } & \multicolumn{2}{c}{ Mutasi gen pintu voltase kanal ion Na+ } \\
\cline { 2 - 3 } & Tidak ada mutasi & Ada mutasi \\
\hline SCN IA & -- & 19 \\
SCNIA disertai SCNIB & & 12 \\
SCNIA dan SCNIB (as. amino polar $\rightarrow$ non polar ) & -- & 2 \\
SCNIA dan SCNIB (as. amino nonpolar $\rightarrow$ non polar) & -- & 1 \\
SCNIA dan SCN IB (asam amino non polar $\rightarrow$ polar $)$ & -- & 9 \\
${ }^{*}=36$ & &
\end{tabular}

Tabel 4. Mutasi gen pada kelompok kejang demam tidak berulang maupun berulang

\begin{tabular}{|c|c|c|c|}
\hline \multirow{2}{*}{ Mutasi gen kanal pintu ion $\mathrm{Na}+$ SCNIA dan SCNIB } & \multicolumn{2}{|c|}{ Kejang demam n(\%) } & \multirow{2}{*}{$\begin{array}{c}p \\
\text { Tes Kruskal- } \\
\text { Wallis }\end{array}$} \\
\hline & Tidak berulang & Berulang & \\
\hline Tidak mutasi & $2(40)$ & $3(60)$ & \multirow{6}{*}{$p<0,05$} \\
\hline Mutasi pada SCN IA & $3(15,8)$ & $16(84,2)$ & \\
\hline Mutasi SCN IA dan SCN IB (non polar - non polar) & 0 & $1(100)$ & \\
\hline Mutasi SCN IA dan SCN IB (non polar $\rightarrow$ polar) & $2(22,2)$ & $7(77,8)$ & \\
\hline Mutasi SCN IA dan SCN IB (polar $\rightarrow$ non polar) & $1(50)$ & $1(50)$ & \\
\hline Total & $6(19,4)$ & $25(80,6)$ & \\
\hline
\end{tabular}

Tabel 5. Hubungan antara channelopathy dan beberapa faktor risiko kejang demam

\begin{tabular}{lcc}
\hline \multicolumn{1}{c}{ Variabel } & $\begin{array}{c}\text { Koefisien } \\
\text { korelasi }\end{array}$ & $p$ \\
\hline Umur & $-0,359$ & 0,03 \\
Suhu & $-0,339$ & 0,04 \\
Jarak antara demam dengan kejang & $-0,086$ & 0,61 \\
Riwayat keluarga (first degree relative) & 0,278 & 0,10 \\
Jenis bangkitan kejang & $-0,155$ & 0,36 \\
Frekuensi kejang demam berulang & 0,044 & 0,82 \\
\hline
\end{tabular}

kanal voltase ion $\mathrm{Na}^{+}$subunit $\alpha$ (SCNIA) terjadi pada $19(61,3 \%)$ pasien dan subunit $\alpha$ (SCNIA) disertai subunit $\beta$ (SCNIB) $12(38,7 \%)$ pasien. Mutasi gen pintu kanal voltasi ion $\mathrm{Na}^{+}$disebut channelopathy (Tabel 3).

Mutasi gen pintu kanal voltase ion $\mathrm{Na}^{+}$subunit $\alpha$ (SCN IA) berakibat delusi nukleotida sestein (C), sehinggga terjadi perubahan kodon 1627 CGA menjadi 1627 GAG. Perubahan kodon ini mengakibatkan pergantian asam amino arginin (R) nomor 1627 dengan asam amino asam glutamat (Glu) (Arg1627Glu) (mutasi missense) dan kodon stop (TGA) (mutasi nonsense). Kodon stop mengakibatkan rantai asam amino penyusun pintu kanal voltase subunit $\alpha 1$ (SC N IA) lebih pendek dari ukuran normal.

Mutasi gen pintu kanal voltase ion $\mathrm{Na}^{+}$subunit $\beta$ (SCNIB) mengakibatkan perubahan jenis dan sifat asam amino penyusun pintu voltase kanal ion $\mathrm{Na}^{+}$pada 5 kodon. Mutasi tersebut bersifat heterozigot. Mutasi tersebut terjadi pada (1) kodon 130 , terjadi pergantian asam amino asam glutamat (GAA) bersifat polar menjadi asam amino lisin (AAA) bersifat non polar (GAA/ AAA), 2) kodon 96 terdapat perubahan asam amino arginin (CGG) bersifat polar menjadi triptopan (TGG) bersifat nonpolar (CGG/TGG), (3) kodon 95 terdapat perubahan asam amino serin (AGC) bersifat polar menjadi asam amino asparagin (ATT) bersifat polar (AGC)/(ATT), (4) kodon 138 terdapat perubahan asam amino valin (TGC) bersifat non polar menjadi asam amino isoleusin (ATC) tetap non polar (TGC/ ATC), dan (5) kodon 154 terjadi perubahan asam amino alanin (GCT) bersifat non polar menjadi asam amino asparagin (ATT) bersifat polar (GCT/ ATT). Channelopathy pada kelompok kejang demam berulang $(80,6 \%)$ berbeda bermakna dibanding kelompok tidak berulang (19,4\%), $p<0,05$ (Tabel 4).

Terdapat hubungan bermakna antara channelopathy dengan umur, suhu saat terjadi bangkitan kejang 
Tjipta Bahtera dkk: Faktor Genetik Sebagai Risiko Kejang Demam Berulang

Tabel 6. Analisis univariat faktor genetik sebagai risiko kejang demam berulang

\begin{tabular}{lccccc}
\hline \multicolumn{1}{c}{ Variabel } & B & Wald & P & RR & C I 95\% \\
\hline Riwayat ayah dengan kejang demam & 0,698 & 1,812 & 0,17 & 2,011 & $0,727-5,560$ \\
Riwayat ibu dengan kejang demam & 1,216 & 6,904 & 0,01 & 3,374 & $1,362-8,358$ \\
Riwayat saudara dengan kejang demam & $-0,375$ & 0,277 & 0,59 & 0,598 & $0,170-2,774$ \\
Riwayat first degree relative dengan kejang demam & 1,066 & 8,344 & 0,004 & 2,903 & $1,409-5,984$ \\
Mutasi kanal SCN IA & 1.269 & 1.309 & 0,253 & 3.556 & $0,405-31.23$ \\
Mutasi kanal SCNIA, kanal SCN IA disertai SCNIB & 1.022 & 1.004 & 0.316 & 2.778 & $0.376-20.500$ \\
\hline
\end{tabular}

Analisis multivariat tidak dikerjakan karena variabel mutasi gen kanal ion $\mathrm{Na}+\mathrm{p}>0,25$

demam pertama (koefisien korelasi berturut-turut $-0,359 ;-0,339 ;(p<0,05)$. Adanya channelopathy berakibat bangkitan kejang demam terjadi pada umur lebih muda dan suhu tubuh lebih rendah (Tabel 5).

\section{Riwayat keluarga pernah kejang demam sebagai faktor risiko kejang demam berulang}

Pasien yang mempunyai ibu dengan riwayat kejang demam mempunyai risiko tiga kali untuk terjadi serangan kejang demam berulang (RR 3.374, KI $95 \% 1.362-8.358, p<0,05)$. Sedangkan pasien yang mempunyai keluarga (first degree relative) dengan riwayat kejang demam mempunyai risiko 2-3 kali terjadi bangkitan kejang demam berulang (RR 2.903, KI 95\%1,409-5.984, $p<0,05)$. Ayah dan saudara kandung dengan riwayat kejang demam tidak bermakna sebagai faktor risiko untuk timbul bangkitan kejang berulang $(p>0,05)$ (Tabel 6).

\section{Mutasi gen sebagai faktor risiko kejang demam berulang}

Mutasi gen pada pintu kanal-voltase ion $\mathrm{Na}^{+}$subunit $\alpha$ (SCNIA) dan $\beta$ (SCNIB) (channelopathy) tidak bermakna sebagai faktor risiko timbulnya bangkitan kejang demam berulang $(p>0,05)$. Channelopathy disertai dengan riwayat keluarga (first degree relative), umur (bulan), suhu tubuh (derajat Celsius), jarak waktu antara mulai demam dan bangkitan kejang, jenis kejang, dapat dipakai menyusun fungsi diskriminan untuk memprediksi terjadi bangkitan kejang demam berulang, dengan derajat ketepatan $88,5 \%$. Fungsi diskriminan unstandardized yang terbentuk adalah $\mathrm{D}=22,020+0,051$ (umur) $-0,612$ (suhu) $+0,039$ (periode waktu) - 0,556 (jenis kejang) + 0,367 (riwayat keluarga dengan kejang demam) + 0,190 (mutasi genetik), dengan cut off point $(-0,517 \times 20+1,724$
Tabel 7. Kesimpulan klasifikasi

\begin{tabular}{lccc}
\hline \multirow{2}{*}{ Kejang berulang } & \multicolumn{2}{c}{ Prediksi kelompok } & \\
\cline { 2 - 3 } & Tidak & Ya & \\
\hline Tidak (n, \%) & $5(83,3)$ & $1(16,7)$ & 6 \\
Ya (n, \%) & $2(10)$ & $18(90)$ & 20 \\
\hline
\end{tabular}

Confusion matrik $88,5 \%$

x 6) $: 26=0,00015$. Nilai di bawah 0,00015 berarti pasien akan mengalami bangkitan kejang demam berulang (Tabel 7).

\section{Pembahasan}

Umur pasien pada saat bangkitan kejang demam pertama $(16,6 \pm 9,8)$ bulan, umur termuda 2 bulan dan tertua 58 bulan (Tabel 1). Batas umur termuda dalam batasan kejang demam pertama menurut International League Against Epilepsy Commission on Epidemiology and Prognosis (ILAE) adalah 1 bulan, sedangkan menurut National Institutes of Health Consensus Conference (NIH) 3 bulan dan tertua 60 bulan. ${ }^{8,9}$ Terdapat hubungan antara umur saat terjadi bangkitan kejang demam dengan kelainan channelopathy (koefisien korelasi 0,359, $p=0,03$ ) (Tabel 5) Channelopathy mengakibatkan bangkitan kejang demam pertama terjadi pada umur lebih muda. Adanya channelopathy akan mengganggu fungsi normal pintu kanal voltase ion. Hal ini mengakibatkan peningkatan $\mathrm{Na}^{+}$influx sehingga meningkatkan excitability membran sel. ${ }^{10}$ Disamping itu channelopathy akan mengganggu spreading depression yaitu proses homeostasis membran sel terhadap perubahan ion. Spreading depression terkait dengan umur. ${ }^{11}$

Suhu tubuh sewaktu kejang demam pertama terjadi terendah $37,5^{\circ} \mathrm{C}$ dan tertinggi $42^{\circ} \mathrm{C}$, dengan rerata 
Tjipta Bahtera dkk: Faktor Genetik Sebagai Risiko Kejang Demam Berulang

$(39,1 \pm 0,82)^{0} \mathrm{C}$, suhu tubuh tersering terjadi bangkitan kejang demam pertama $39^{\circ} \mathrm{C}$ (Tabel 1). Penelitian di Oulu Finland, Ratala $\mathrm{H}$ dkk melaporkan suhu tubuh pasien kejang demam $39,4^{\circ} \mathrm{C}$ sedangkan suhu tubuh pasien tidak mengalami kejang demam $38,8^{\circ} \mathrm{C}$ $(p=0,01) \cdot{ }^{12}$ Ada korelasi bermakna antara channelopathy dengan suhu tubuh saat terjadi bangkitan kejang demam (koefisien korelasi 0,339, $p=0,04$ ) (Tabel 5) Channelopathy dapat mengakibatkan bangkitan kejang demam berulang pada suhu lebih rendah. Channelopathy dapat mengakibatkan temperatur sensitif, sehingga bangkitan kejang demam terjadi pada suhu tidak tinggi $\left(\leq 38^{\circ} \mathrm{C}\right) \cdot{ }^{13,14}$

Limapuluh enam $(37,84 \%)$ pasien kejang demam pertama mengalami kejang demam berulang. Peneliti lain sepertiga kasus kejang demam pertama akan mengalami kejang demam berulang, 5,15 94,7\% kejang demam berulang terjadi dalam waktu 24 bulan pasca kejang demam pertama. Peneliti terdahulu mendapatkan $90 \%$ kejang demam berulang terjadi dalam waktu 24 bulan pasca kejang demam kali pertama. ${ }^{2,7,16}$

\section{Riwayat keluarga sebagai faktor risiko bangkitan ulang kejang demam}

Pasien kejang demam mempunyai riwayat keluarga pernah menderita kejang demam, masing-masing ibu $16,2 \%$, ayah $11,5 \%$, saudara kandung 6,8\% dan first degree relative $30,4 \%$ (Tabel 2). Peneliti terdahulu mendapatkan dengan ibu mempunyai riwayat pernah menderita kejang demam 12,5\%. Perbandingan pewarisan antara ibu dan ayah $27 \%$ dibanding $7 \% .{ }^{17}$ Peneliti mendapatkan ibu dan keluarga (first degree relative) dengan riwayat pernah menderita kejang demam merupakan faktor risiko terjadi bangkitan ulang kejang demam 3,3 kali (KI95\% 1,368-8,358); dan 2,9 kali (KI1,409-5,984), saudara kandung dan ayah dengan riwayat pernah menderita kejang demam bukan merupakan faktor risiko untuk terjadi bangkitan ulang kejang demam. Peneliti lain mendapatkan pasien yang mempunyai keluarga dengan riwayat pernah menderita kejang demam bukan merupakan faktor risiko untuk terjadi bangkitan kejang demam berulang. ${ }^{3}$ Penelitian Hauser dkk, mendapatkan bahwa pasien kejang demam yang mempunyai saudara pernah menderita kejang demam mempunyai risiko terjadi kejang demam 2,7\% (KI 95\% 2.0-3.6), apabila salah satu orang tua mempunyai riwayat pernah menderita kejang demam, risiko meningkat menjadi
10\% (KI 95\% 6.3-15) dan apabila ke dua orang tua mempunyai riwayat pernah menderita kejang demam risiko meningkat 20\% (KI 95\% 9.6-36.8). ${ }^{18}$ Pasien kejang demam pertama yang mempunyai keluarga (first degree relative) pernah menderita kejang demam mempunyai risiko 50\%-100\% untuk terjadi bangkitan kejang demam berulang. ${ }^{1,7,19}$

\section{Mutasi gen sebagai faktor risiko kejang demam berulang}

Channelopathy tidak bermakna sebagai faktor risiko kejang demam berulang. $(p>0,05)$, hal ini karena subjek kurang. Disamping itu mutasi gen pada pintu kanal-voltase ion subunit $\beta$ (SCNIB) bersifat heterozigot, sehingga fungsi modulasi terhadap pintu voltase kanal ion subunit $\alpha$ (SCNIA) tidak terganggu. Peneliti terdahulu mendapatkan bahwa mutasi gen pada pintu kanal voltase ion $\mathrm{Na}^{+}$subunit $\alpha$ (SCNIA) berhubungan tetapi tidak bermakna pada kejang demam berulang. ${ }^{20}$ Meskipun demikian channelopathy pada kelompok kejang demam berulang berbeda bermakna dibandingkan pada kejang demam tidak berulang ( $p<0,05$, Tabel 4). Channelopathy, umur, suhu tubuh, periode waktu antara demam dengan bangkitan kejang, jenis kejang, dan riwayat keluarga pernah kejang saat kejang pertama dapat dipakai prediktor timbulnya bangkitan kejang, dengan ketepatan $88,5 \%$ (Tabel 7).

Tiga (6,3\%) kasus kejang demam berulang tidak diketemukan adanya channelopathy (Tabel 4). Hal ini dapat terjadi karena pemeriksaan mutasi gen pintu voltase kanal ion $\mathrm{Na}^{+}$hanya dikerjakan di kromosom 2q24 di exon 26 untuk pintu kanal voltase ion subunit $\alpha$ (SCN IA) dan untuk pintu voltase kanal subunit $\beta$ (SCN IB) di kromosom 19q3 exon 3 . Masih terdapat 18 lokus mutasi pintu kanal-voltase subunit $\alpha 1$ (SCNIA) dan subunit $\beta 1$ (SCNIB) serta dua mutasi pada reseptor GABA A subunit $\gamma 2$.yang berperan terjadi peningkatan excitability membran sel, pada penelitian kami tidak diperiksa. ${ }^{21-25}$ Lagi pula tidak seluruh rantai polinukleotida penyusun DNA pada pintu kanal-voltase ion subunit $\alpha$ (SCNIA) yang berjumlah 6001 tidak diperiksa, tetapi hanya 76 asam amino. Peneliti terdahulu mendapatkan 17\% dari 53 kasus GEFS + tidak diketemukan channelopathy Sebaliknya hasil pemeriksaan kromosom 2q24 exon 26 dan 19q13 exon 3 terdapat mutasi gen pintu kanal-voltase ion $\mathrm{Na}^{+}$subunit $\alpha$ (SCNIA) dan subunit 
$\beta$ (SCNIB) tetapi pasien tidak mengalami bangkitan kejang demam berulang (13,4\%, Tabel 4). Hal ini karena terjadi pengurangan penetrasi berkisar 60 $90 \%$ pada pewarisan gen sehingga walaupun genotip terdapat channelopathy tetapi fenotip normal. ${ }^{24,26,27}$

\section{Kesimpulan}

Sepertiga kasus kejang demam pertama mengalami bangkitan ulang kejang demam dan sebagian besar terjadi pada 12 bulan pasca kejang demam pertama. Riwayat ibu atau keluarga (first degree relative) merupakan faktor risiko terjadi kejang demam berulang. Channelopathy tidak bermakna sebagai faktor risiko terjadi kejang demam berulang. Pada kelompok kejang demam berulang didapatkan channelopathy lebih banyak dibanding tidak mengalami kejang demam berulang $(p<0,05)$. Channelopathy mempunyai korelasi dengan umur dan suhu pada saat pertama mengalami kejang demam pertama, dan dapat dipakai sebagai prediktor timbulnya bangkitan kejang berulang.

\section{Daftar Pustaka}

1. Berg A T, Shinar S, Darefsky A S, Holford T R, Shapiro E D, Salomon E D, et al. Predictors of recurrent febrile seizures: A prospective cohort study. Arch Pediatr Adolesc Med 1997; 15:371-8.

2. Offringa M. Risk factors for seizure recurrence in children with febrile seizures: A pooled analysis of individual patient data from five studies. J Pediatr 1994;124:57484.

3. Tarkka R, Rantala H, Uhari M, Pokka T. Risk of recurrence and outcome after the first febrile seizure. Pediatr Neurol 1998;18:218-20.

4. Waruiru C, Appleton R. Febrile seizures: an update. Arch Dis Child 2004;89:751-6. Diunduh dari URL: http:// www.bmjjournals.com/subscriptions/

5. Berg AT. Recurrent febrile seizures. Dalam: Baram FZ, Sinnar S, penyunting. Febrile seizures. San Diego: Academic Press; 2002. h. 37-49.

6. Corey I A, Pellock J M, Boggs J G, Miller L L, Del orenzo R J. Evidence for genetic predisposition for status epilepticus. Neurology 1998;50:558-60.

7. Berg AT, Sinnar S, Hauser A, Alemany M, Shapiro ED. A prospective study of febrile seizures. N Engl J Med 1992;327:1222-7.
8. National Institutes of Health Consensus Development Conference Statement. Febrile seizures. NIH Consents statement online 1980;3:1-10.

9. Commission on Epidemiology and Prognosis. International League Against Epilepsy. Guidelines for epidemiologic studies on epilepsy. Epilepsia 1993;34:592-3.

10. Uhari M, Rantala H, Vainionpaa L, Kurttila R. Effect of acetaminophen and a low intermittent doses of diazepam on prevention of recurrences of febrile seizures. J Pediatr 1995;126:991-5.

11. Wu J, Fisher RS. Hyperthermic spreading depressions in the immature rat hippocampal slice. J Neurophysiol 2000;84:1355-60.

12. Ratala $H$, Uhari $M$, Hietala J. Factors triggering in first febrile seizures. Acta Paediatr.1995;84:407-10.

13. Fujiwara T, Sugawara T, Mazaki-Miyazaki E, Takahashi Y, Fukushima K, Watanabe M, dkk. Mutations of sodium channel alpha subunit type 1 (SCNIA) in intractable childhood epilepsies with frequent generalized tonicclonic seizures. Brain 2003;126:513-4.

14. Hirose S, Mohney RP, Okada M, Kaneko S, Mitsudome A. The genetics of febrile seizures and related epilepsy syndromes. Brain \& Development 2003;25:304-12.

15. Stafstrom C E. The incidence and prevalence of febrile seizures. Dalam: Baram TZ, Shinnar S, penyunting. Febrile seizures. SanDiego: Academic Press; 2002:16.

16. Berg AT, Sinnar S, Houser, Leventhal JM. Predictors of recurrent febrile seizures: a meta analytic review. J Pediatr 1990;116:329-37.

17. Doose H, Maurer A. Seizure risk in offspring of individual with a history of febrile convulsions. Eur J Pediatr 1997;156:476-81.

18. Hauser WA, Anneger J E, Anderson V E, Kurland L T. The risk of seizures disorders among relatives of children with febrile convulsions. Neurology. 1985;35: 1268-73.

19. H irtz G D. Febrile Seizure. Pediatr in Rev 1997;18: 5-8.

20. Ching Chou I, Tien Ping C, Tsai F, Ching Huang C, Ru Shi Y, Han Tsai C.. The lack of association between febrile seizures and polymorphisms in SCNIA. Epilepsy Res 2003;54:53-7.

21. Escayg A, Heils A, MacDonald B T, Haug K, Sander T, Meisler M H . A novel SCN1A mutation associated with generalized epilepsy with febrile seizures plus and prevalence of variants in patients with epilepsy. Am J Hum Genet 2001;68:866-73. 
22. Ito M, Nagafuji H, Okazawa H, Yamakawa K, Sugawara T, Mazaki-Miyazaki E, dkk. Autosomal dominant epilepsy with febrile seizures plus with missense mutations of the $\left(\mathrm{Na}^{+}\right)$-channel $\alpha 1$ subunit gene, SCNIA. Epilepsy Research 2002;48:15-23.

23. Wallace RH, Scheffer LE, Parasivam G, Barntt S, Wallace GB, Sutherland GR, dkk. Generalized epilepsy with febrile seizures plus: Mutation of the sodium channel subunit SCN1B. Neurology 2002;58:1426-9.

24. Marini C, Harkin L A, Wallace R H, Mulley J C, Scheffer I E, Berkovic S F. Childhood absence epilepsy and febrile seizures: a family with a GABA A receptor mutation.
Brain 2003;126:230-40.

25. C, Scheffer I E, Berkovic S F. Childhood absence epilepsy and febrile seizures: a family with a GABA A receptor mutation. Brain 2003;126:230-40.

26. Nakayama J, Hamano K, Noguchi E, Horiuchi Y, Iwazaki N, Okta M, dkk. Failure to find causal mutations in the GABA A receptor Y2 subunit (GABRG2) gene in Japanese febrile seizures patients. Neurosc lett 2003;343:117-20.

27. Johnson GW, Kugler SL, Stenroos ES, Meulener MC, Rangwalla 1, Johnson TW, dkk. Pedigree analysis in families with febrile seizures. Am J Med Genet 1996;61:345-52. 